\title{
Is There a Feminist Text in Jane Eyre?-A Reappraisal
}

\author{
Yinghuei Chen \\ Asia University, Taichung, Taiwan
}

\begin{abstract}
After the publication of Virginia Woolf's A Room of One's Own (1929), which to many critics marked the beginning of a sustained thinking about women writing and feminist literary theory, it has become a commonplace to read Jane Eyre as a feminist text. Evidences in the novel, though not abundant, can be found to support such a reading. But Jane Eyre is not an enumeration of the rights of women, neither is it a manifesto or a catalogue of wrongs done unto women by society. Wherever the text refers to women having similar ambitions to men, as shown in a passage often quoted in Chapter XII of the book, we must bear in mind that Jane, an orphan placed in an unloving home, a brutal school and an unsympathetic employment environment, must make her way in life as best she can. She has no time for feminist sentiment, her survival allows for nothing outside of her own labor. To suggest that Jane is expressing herself as a feminist by taking up employment is ludicrous; she is merely surviving as countless male characters likewise do.

Jane's pragmatism is given further heft by her reaction to Bertha's death. Bertha dead is a problem solved, a barrier removed. If she has to tweak the narrative to allow for this then she will, the ex-servant's reiteration of Bertha's death is pregnant with self justification, not his but Jane’s. Indeed Jane's good sense, adaptability and, above all, awareness of her personal circumstances are given as causes for her pragmatic decision-making. This may seem a brutal scheme of values but it is all she has to work with. Rather than searching for Brontë's true voice in the text and, thereby, attempting to graft onto it a proto-feminism, we should instead recognize Jane's true voice coming through that of the ex-servant. Far from being feminist, a thought Jane cannot indulge, she is the supreme realist, willing, in the final analysis to disregard even murder in the pursuit of her own safety and repose. Jane is an expression of Brontë in that both are women of dubious background, seeking success in a world so far out of their control that they must use any and all means either in their possession or available to them via an outside agency to get on.
\end{abstract}

Keywords: women writing, feminist, a feminist text, proto-feminism, pragmatism realist

The Brontës, like the characters they created, emerge to us as out of "an "atmosphere of mist,"1 the truth of their personalities colored, or rather desaturated, by the overawing power of their works and the impenetrability of their provenance, motivations and intentions.

Charlotte, the eldest and with four novels the most prolific, could be cast as the most worldly, although

Yinghuei Chen, Ph.D., Prof. \& Dean, Dept. of Foreign Langs. \& Lit., Asia University, Taichung, Taiwan.

1 This is how Sydney Dobell, one of the earliest critics of Wuthering Heights, describes the figures in the novel, then thought mistakenly written by Currer Bell (i.e., Charlotte Brontë). For Dobell'sarticle in Palladium see Norton Critical Edition of Wuthering Heights, ed. Richard J. Dunn (New York: W. W. Norton, 2003), pp. 293-298. 
that word's exact meaning shifts with the age in which it is used. Certainly she must have been the child most involved with the upbringing of her siblings, never mind that she was five years old at the death of her mother and nine when her sisters Maria and Elizabeth succumbed to tuberculosis. Her aunt Elizabeth Branwell, by all accounts a strict and puritanical guardian ${ }^{2}$, while supplying the house with organization, also saw to it that Charlotte was enlisted as a maid of all works in the care of her surviving family members.

Attempting to gauge this period with regard to its effect on the future writer is to get entangled in far too much speculation as there is a paucity of details to draw upon. Suffice it to say that a gloomy location coupled with an atmosphere of bereavement and loss, however stoically received, can be assumed to have had an influence on the writers in that family. It seems futile to parse the degree with which each sister dealt with the exigencies of her situation; certainly the received knowledge is that Charlotte, a more gregarious character was, by that token, a better informed and more militant writer. This is, at best, controversial and we should confine ourselves to saying that in her novels there is an awareness of and engagement with the world beyond the shores of England. Indeed, any approach to Charlotte Brontë's work requires a quick survey of the prospects and opportunities available to a woman of her background in 1840s England. This is important in understanding the world through which she, and by extension her characters, moved.

What was there for a woman to do, should she require employment in the early Victorian period? In this case we need to understand the particular situation, Charlotte's situation which was that of a woman who lacked fortune and family connections but who had some education. ${ }^{3}$ Earning a living was then a profoundly difficult matter bound up in issues of class, status and personal pride. The Brontës were, essentially, nobodies, their European inflected patronymic (a construct) ${ }^{4}$ gave them the patina of gentry as did their father's position in the church and they had to leverage these slight advantages as best they could. Having received an education, how should she then turn that to account?

The year 1842 brought a moment of decision, the departure of Charlotte and Emily for Europe where they took positions as teachers in a private boarding school. ${ }^{5}$ The dislocation felt by such hitherto provincial girls is hard to imagine as is the probable sense of apprehension and homesickness, which was to culminate in Charlotte developing an attraction to her employer at the Pensionnat Héger, a romance which was impossible, as M. Heger was married. Once again it is wisest not to try to appraise the feelings involved as we are in no position to do so with any exactitude. Whatever the case Charlotte found herself alone in the school the best part of a year and finally quit her job and went home in 1844. This time was to furnish her with a great deal of information and material for her books the first of which, The Professor, was completed in 1846 although unpublished till $1857 .^{6}$

Having some awareness of how a woman of Charlotte's background could make shift for employment, we must now look at what it meant to be either a teacher or a governess in the 1840s, and once again this subject

\footnotetext{
${ }^{2}$ Much of the Brontës's real life at home has been somewhat hijacked by Elizabeth Gaskell's biography of the family: The Life of Charlotte Brontë (1857) in which aunt Elizabeth is a marginal character.

${ }^{3}$ Many of the details of Lowood in Jane Eyre derived from Brontë’s time at the School for Clergymen's Daughters at Cowan Bridge (1824), then at Roe Head School in Mirfield, where she later taught from 1835 to 1838.

${ }^{4}$ Because of his admiration for Lord Nelson, who was bestowed the honor of Duke of Brontë in 1799 by King of Ferdinand of Naples, Patrick changed his surname from Brunty to Brontë.

5 The Pensionnat Héger.

${ }^{6}$ Posthumously, by her husband, Arthur Bell Nicholls.
} 
requires some knowledge of the British class system. ${ }^{7}$ For a woman born between the great classes, by which I mean the upper and lower within which social roles were clear, it was always a struggle to find a way to live should means be lacking. There were many opportunities to fail and penury was never far away. For the most part women in Charlotte's situation considered themselves above menial work. For them there were the positions of governess or companion, both of which, though paid, were vague enough in terms of status to make one neither a servant nor a household member. To navigate this no man's land, somewhere between the classes was no easy feat, and we need to look no farther than poor Lucy Snowe who in Villette (1853) tries to be first a companion and then a teacher, finding happiness in neither. As a governess, she would be subject to her employer's caprices but she might also enjoy considerable autonomy depending on the degree of interest parents might have in their child's education.

Within the flexible dynamic of the governess/employer relationship, freighted as it was with class and status issues and the concomitant difference in circumstances, she could indulge in many possible fantasies if she were so inclined. The constrictions under which women from "good" families labored were such that these careers, menial though many were in reality, could be attractive to those dwelling in the halfway world conferred on them by having education but no position. Nevertheless, to be employed was to suffer the constant threat of dismissal, to be out of place and facing poverty.

From this brief sketch of the conditions under which these positions were held, we can move on to wonder how a woman who has experience of them would express herself should she be a writer. Within this particular field we may be well advised to dispense with the dubious label of feminism, a term which considerably postdates Brontë's period. ${ }^{8}$ If Brontë chose to intrude her voice into the text of Jane Eyre, as Virginia Woolf points out in her derogatory remarks on Brontë in A Room of One's Own ${ }^{9}$, then it is a tribute to the strength of her construction of Jane that such an intrusion needs to be identified by critics while the general reader notices nothing untoward in the narrative. Could this inference be in opposition to the writer's intention, certainly the text accommodates such material comfortably.

Bertha Mason, Mr. Rochester's wife and the thwarter of his plans for Jane, is a pivotal figure in the novel. ${ }^{10}$ She is at once vocal, both in her own ferocity and her value to others in manipulating the affairs of her husband, and silent having not one single line of speech in the entire book. She is mad, so we are told and so it appears, the source of her mania deriving entirely from Rochester's narrative of it. She is rich, or certainly richly dowered, the source of her initial attractionto Mr. Rochester. She is concealed, though ineffectively, as

\footnotetext{
7 The Brontës, unfortunately, were unlanded and untitled. For further references see Asa Briggs, A Social History of England (London: Weidenfeld and Nicolson, 1983). Also see Peter Wood, Poverty and the Workhouse in Victorian Britain (Phoenix Mill: Sutton Pub. Ltd, 1991).

8 The Oxford English Dictionary lists 1894 for the first appearance of "feminist" and 1895 for "feminism". See Oxford English Dictionary, 2nd ed. (Oxford: Clarendon Press, 1989).

9 Virginia Woolf criticized Charlotte Brontë’s authorial voice in Ch. 4 of A Room of One's Own, stating that "She left her story, to which her entire devotion was due, to attend to some personal grievance.” See A Room of One's Own and Three Guineas. Oxford: Oxford UP, 1992, pp. 88-90. For Woolf's critical view of Brontë see also The Common Reader, First Series (New York: HBJ, 1932). Sandra M. Gilbert and Susan Gubar in their thought-provoking book The Madwoman in the Attic have also argued that it is rage over women's social inferiority that both inspires and informs Charlotte Brontë's writing. See The Madwoman in the Attic: The Woman Writer and the Nineteenth-Century Literary Imagination (New Haven: Yale UP, 1979).

10 To give Bertha Mason her due, Jean Rhys, herself a Creole, published in 1966 her best known novel Wide Sargasso Sea, a prequel to Jane Eyre, placing Bertha as the central character in that novel and providing the Caribbean back-story of Antoinette (known as Bertha in Jane Eyre).
} 
she makes various appearances throughout the book. She is of a family well thought of, though the admiration may be more for the money than the name. Finally she is transplanted, having come from her native West Indies to the gloomy moors of North England. Bertha lacks a coherent narrative, yet she intrudes herself into the genteel courtship underway at Thornfield Hall, and she dares to burst from her confinement and enter at various times Rochester's and Jane's bedrooms, private areas one of which, as wife, she should be privy to. She furtively roams the house which by conjugal rights she should be mistress of.

The origins of Bertha are concisely stated — she is a Creole mad and of a mad family. This is accepted by those around Rochester, evidence seemingly limited to the vision of an infuriated figure in a darkened room. Subtle hints of the unreliability of this evidence abound, not less Grace Poole's fondness for liquor, a prop, we are told, in her unenviable profession of keeper of a lunatic and not as may be surmised a weakness deriving from her wish to forget the truth of Bertha's situation. No matter, let us proceed with the case as the narrative gives it. Bertha, a mad woman of mad stock resides in Rochester's upper rooms, tended by Grace Poole and subject to occasional wanderings through Thornfield proper. Her attempt on her brother Richard Mason's life takes place during Rochester's house party during which he embarks on a very ostentatious wooing of the glittering Blanche Ingram, a character diametrically opposite to not only Bertha but Jane herself. The significance of her name should also be noted because where Bertha is black, Blanche is explicitly labeled white. It is at this moment that Bertha strikes, her weapon her teeth, his savior Jane, a bizarre triangle, with feral behavior as its transcendent element.

"She sucked the blood: she said she'd drain my heart," said Mason (p. 187) ${ }^{11}$. This indirect speech is, incidentally, Bertha's sole articulation. This moment with its direct allusion to vampirism is important as it is exactly that monster which Jane compares Bertha to in Chapter XXV. It is possible that Jane, privy to Bertha's violence and subject to her premarital visit in Chapter XXV is slyly referencing the former in her description of the latter, showing an understanding of the situation which Rochester imagines her ignorant of.

Is it mania which propels this attack? Is draining Mason, the brother, a metaphor for his draining of Bertha in the unhappy marriage she was coerced into? Confined as she is, perhaps we have some sympathy for her launching an assault on one whose filial duties as protector seem to have been entirely abrogated. Is Bertha then, while a living character, a representation of or perhaps a proxy for Jane at her most wild and abandoned self? Has Jane, subject as she has been to constant limitations in her life, somehow found common ground with Bertha in expressing the wildness of the unleashed feminine psyche?

While it is no accident that the attempt on Mason's life takes place during Rochester's courtship of another, be aware the objection to Rochester's marriage to Jane is on the grounds of bigamy and to Bertha, surely, Thornfield is the marital home. This sets up another strange dynamic as Jane describes the dashing of her hopes upon witnessing Blanche's perfection in contrast to her own dowdiness, going so far as to paint comparative studies of them both. How then should Bertha feel-aware of the merriment in the house while confined and ostracized? As wife it is for her to feel jealousy and why should she hold off from attempting to disrupt her husband's plans? It is also clear that, Bertha's violence having taken place, Jane is happy to transfer its blame to Grace Poole, a placid character upon whom Jane can surely not lay this animal attack on top of the guilt of

${ }^{11}$ Charlotte Brontë, Jane Eyre (4th ed.), A Norton Critical Edition, ed. Richard J. Dunn (New York: W. W. Norton, 1971). Hereafter quotations cited from the novel refer to this edition. 
arson which she was witness to earlier. Mr. Rochester's connivance at this lie is matched by Jane's, a prelude to Bertha's next appearance. Jane's suspicions must become more concrete as these manifestations of a dangerous female presence continue.

Perhaps her suitability for Rochester lies herein as the disadvantages attendant on marriage to him. Mad wife notwithstanding would, in her scale of reckoning, be far outweighed by the pecuniary gains. Is this not a mirror image of how Bertha was sold to Rochester? In both cases lunacy, whomsoever it afflicts, is no barrier to remunerative matrimony. By making Jane complicit in Bertha's ravings we begin to suspect Rochester's desires as regards her. Certainly the self serving Blanche would not have scrupled to concern herself with Bertha, ridding herself of an inconvenient encumbrance as soon as possible.

Once again money is an imperative in all these schemes. Blanche wishes to ally with Rochester for financial motives, and Rochester, whatever reasons he gives for the marriage to Bertha, profits enormously from the match. As second son he may not have his due a huge inheritance, so the wealth through marriage may not have been unwelcome. Indeed, we are left to ponder whether the life of traveling and mistresses which Rochester relates was financed with Bertha's money. This certainly places a different construction on Rochester's so called despair subsequent to his marriage.

The exigencies of money are certainly never far away in Jane Eyre, and she herself suffers from the start not due to her orphan status but her dispossessed state. The poor relative, a stock character in British life, ${ }^{12}$ is here given place in the house due to a quickly regretted promise to keep her. This drain on the house's resources and her condition are things of which she is constantly reminded. Rochester offers a mirror image of this, a son who will not inherit the father's chattels must, nevertheless, have an income. There is no suggestion of Rochester doing without. Enter Bertha. Creole? Yes. Mad? Maybe. Rich? Undoubtedly. She becomes the colonies personified, scorned for their race, abused for their utility and exploited for their wealth. Bertha may not be attractive but her wealth certainly is and which Englishman abroad did not put aside his distaste of the location to benefit from its bounty? We need only look at Sir Thomas Bertram in Austen's Mansfield Park (1818), a character of unquestioned probity and respectability who, ostensibly on account of business, spends many months absent in Antiqua, his whole life style dependant on the income he derives from plantations there.

How his plantations are staffed is not explicitly described although readers would have not need such detail—Sir Thomas Bertram is a slave owner, on a large scale it seems. ${ }^{13}$

“But I do talk to him more than I used. I am sure I do. Did you not hear me ask him about the slave trade last night?”

"I did—and was in hopes the question would be followed up by others. It would have pleased your uncle to be inquired farther."

“And I longed to do it—but there was such a dead silence!”"14 (Ch. 3, Vol. 2)

We may imagine this silence to derive from an unwillingness to discuss an unpleasant subject, the slave trade being controversial, or at least a wish not to couple the gentility of their lifestyle with the misery which

12 The social services were limited to charitable organizations. A deeply telling expression- the undeserving poor.

13 Slavery was not abolished in the British colonies until 1833 (the owners being compensated). Slavery in all British possessions terminated in 1843. In fact, the slave trade had existed in England since 1562 and slavery in England itself had been abolished in 1807 only 7 years prior to Mansfield Park.

${ }^{14}$ Jane Austen, Mansfield Park, A Norton Critical Edition, ed. Claudia L. Johnson (New York: Norton \& Company, 1998). Hereafter quotations cited from the novel refer to this edition. 
funded it. ${ }^{15}$

Subsequent to an abortive marriage, as Rochester terms it, did he reimburse the Masons with their wealth? There is no suggestion of any such thing. £30,000 seems a great deal of money for lodging in an attic when viewed in this light. Indeed Rochester relates the early death of his brother as further proof of his marriage being unnecessary. Rochester's return to England then is a return to sanity, to civilization, Bertha the irremediable alien subsists as the insane remnant of a colonial adventure which requires concealment once these shores have been regained. Subsequently,bigamy, an awful sin, is expiated via the dual extenuations of race and mental condition. The vow for better or worse certainly does not apply in Bertha's circumstances as she is not even to be entirely discarded but she is to dwell instead for however long in her abandoned turret. If Jane cannot become Mrs. Rochester on Bertha's account it is solely for her recognition of his married status.The wife, as a human being, has no impact on Jane's decision whatever.

So much for Bertha and Rochester, but what of quiet, placid put upon Jane? Her intelligence and perceptiveness are manifest. Is she to be judged an innocent in those proceedings? Doubtful though it may be that she truly views the events in Thornfield as the doings of an occasionally deranged servant, a woman who must undergo a nocturnal metamorphosis, Jane cannot really identify with Bertha due to a corresponding connection with violence and darkness resident in her own psyche. Yet it remains the case that Jane fits in very well at Thornfield, as she takes screams, wails, sobs, arson and bloody violence all in her stride and finds time to fall in love. How is Jane so inured to horror?

If Jane has a savage or even vengeful component to her nature, we need to find evidence for it in the text and this is not easy. Her initial condemnation of Mrs. Reed melts upon her aunt's illness, and even her dislike of her cousins Eliza and Georgiana is set aside after Mrs. Reed's death, with Jane forgoing the pleasure of returning to Thornfield in order to selflessly assist them as they prepare to leave Gateshead Hall.

"Mr Rochester had given me but one week’s leave of absence:” said Jane, “yet a month elapsed before I quitted Gateshead” (p. 211). This is not an action of a vengeful enemy; it is quite the opposite. Shortly after this magnanimous gesture, however, comes a turn of phrase which goes beyond savagery and verges on the unspeakable.

"Hasten! Hasten! be with him while you may: but a few more days or weeks at most, and you are parted with him forever!” And then I strangled a new-born agony-a deformed thing which I could not persuade myself to own and rear-and ran on. (p. 214)

Of all the imagery Jane could use to describe her feelings, she settles on this ghastly turn of phrase. How does Jane, whose purity and innocence are so often remarked on, have even an awareness of post natal infanticide here given its most shocking variation: the strangling of the imperfect newborn? This practice was by no means uncommon in 19th century England, being an unmentioned component of a midwife's skill. Indeed more than one woman made a business of it on an industrial scale, finding it lucrative and, after conviction and execution, becoming some of history's most prolific serial killers. ${ }^{16}$

\footnotetext{
${ }^{15}$ For how the colonies financially support the life style and economy of the estates back in England, see Edward W. Said, Culture and Imperialism (New York: Alfred A. Knopf, 1993), in particular his chapter entitled "Jane Austen and Empire.”

${ }^{16}$ Amelia Elizabeth Dyer, a matronly looking woman was executed in 1898 for the murder of an unknown number of infants having accepted a fee for supposedly placing them in new homes, and she was not the only example of this lethal practice. See Alison Rattle \& Allison Vale, Amelia Dyer: Angel Maker: The Woman Who Murdered Babies for Money. London: Andre Deutsch, 2007.
} 
These dreadful goings on should have no place even in the subconscious of so perfect a figure as Jane, yet there it is carrying with it also the overtone of distaste of the deformed and recognition of the necessity of its destruction. Jane's employment of infanticide as a metaphor for the extinguishing of her hopes, now forlorn, for Mr. Rochester is a shocking sentence and lays bare Jane's awareness of the darkest deeds of humanity. If Jane has knowledge of this extremity what else resides in her mind and where did she learn of these things?

In this one sentence we can judge of Jane's facility with ghastly images and ponder her application of them to her own feelings. Is this the only example of a tendency towards the horrible? Perhaps not as, in Chapter XXV, while describing her nocturnal visitation to Rochester she employs this description:

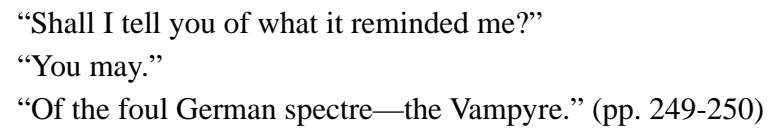

Jane has been by this time witness to several frights in the dark and it is hard to believe she has no suspicions as to the culprit. By comparing Bertha to a vampire, a creature which literally sucks the life from its victims, could she be alluding to the effects marriage to Bertha has had on Rochester's life? Bertha herself is never more tragic, a creature of the night flittering in dismal half light, robbed, in Jane's description, even of the attributes of humanity. Matching this to Jane's reference to infanticide would Bertha be another of the despised deformed and would Jane hesitate to strangle it?

Rochester, then, in his desire to be rid of Bertha has her put away, not uncommon in even the highest classes at that time. ${ }^{17}$ It is peculiar that he does not install Bertha at some far remove, thereby, allowing himself the advantage of distance. Such a situation could have been procured in the West Indies or indeed anywhere at the behest of a man of Rochester's status and means, which has been considerably augmented by Bertha's marriage portion. Why does he suffer himself to convey her by sea to Thornfield? The contempt and disgust he expresses for her would seem to negate the notion that he feels continuing duty toward her or that he has affection for her. Is the narrative incomplete? Would a Bertha put off and put away result in a reapportioning or even refund of her dowry? As a Creole or at best a half-caste (the contemporary term, preferable to Mulatto), is the installation of Bertha in her oubliette at Thornfield the best of a bad job, wherein she can be set aside but not abandoned with some concomitant loss of estate? While in despair in Jamaica and pondering the steps he is to take, which melodramatically and half-heartedly include suicide, he claims to hear the calling from "a wind fresh from Europe.” Revivified, he resolves to return to Europe:

The sweet wind from Europe was still whispering in the refreshed leaves, and the Atlantic was thundering in glorious liberty: my heart, dried up and scorched for a long time, swelled to the tone, and filled with living blood-my being longed for renewal-my soul thirsted for a pure draught. I saw Hope revive-and felt Regeneration possible. From a flowery arch at the bottom of my garden I gazed over the sea-bluer than the sky: the old world was beyond; clear prospects opened thus:- (p. 271)

Rochester’s monologue or inner calling reveals his deep-rooted Euro-centricism, a world view that sees

\footnotetext{
${ }^{17}$ George V's autistic son the lost prince was concealed, his death remaining mysterious, while two mentally ill cousins of his daughter-in-law Elizabeth Bowes Lyon we put away for decades. These events taking place almost a century after the writing of Jane Eyre. For Prince John see Stephen Poliakoff's BBC drama, The Lost Prince, which charts the little-known tale of Prince John, the youngest child of George V and Queen Mary.
} 
Europe as the avatar of progress and civilization. And it is this old world of grace that saves him from despair and self-annihilation in his dire need.

The egocentricity and ethnocentricity of this passage is revelatory for herein lies no mention of Bertha' desire. Rochester pines for home and, in the service of his whim, she is transplanted from home, transported along with his other movables in a ship. How significant is it that so many women of her ethnicity were forcibly embarked for England? Marriage has conferred no immunity from deportation for Bertha. She certainly has not heard "a sweet wind from Europe."

Jane Eyre is not an enumeration of the rights of women, and neither is it in any way a manifesto or a catalogue of wrongs done unto women by society. Wherever the text refers to women having similar ambitions to men, as shown in a passage often quoted in Chapter XII, ${ }^{18}$ there is no clear evidence that such statement should be seen as digressions. At all times we must bear in mind that Jane, an orphan placed in an unloving home, a brutal school and an unsympathetic employment environment, must make her way in life as best she can. She has no time for feminist sentiment, her survival allows for nothing outside of her own labor and this she must find. Here is a universe of absolutes within which she cannot abandon herself to her own whims. She also recognizes the moral ultimate she must respond to, it is then no surprise that, when all these exigencies are brought into play subsequent to her inability to remain at Thornfield after the failed wedding, she comes within a fraction of starvation.

To suggest that Jane is expressing herself as a feminist by taking up employment is ludicrous; she is merely surviving as countless male characters likewise do. The collapse of her world at Whitcross in Chapter XXVIII is the best proof of how Jane has to operate.

Jane's pragmatism is given further heft by her reaction to Bertha's death and here we may open another debate. Did Bertha fall or was she pushed? The facts of her end are related to Jane by an unnamed ex-servant of the Rochester's and his narrative is in turn transmitted by Jane to us. The facts are thus at three removes, should we be suspicious?

"I witnessed, and several more witnessed Mr Rochester ascend through the skylight on to the roof: we heard him call 'Bertha!' We saw him approach her; and then, ma’am, she yelled, and gave a spring, and the next minute she lay smashed on the pavement."

“Dead?”

"Dead? Ay, dead as the stones on which her brains and blood were scattered.” (p. 377)

Let us look at this again. "I witnessed, and several witnessed...” a strange turn of phrase, less a tale and more of a statement aiming at shoring up an alibi.

If this passage seems rather forensic then let us recap Jane's return to Thornfield, bearing in mind hers is our only testimony. Jane has heard a supernatural voice calling her (p. 369, Ch. XXXV) and, impelled by a feeling of being needed has rushed to find Mr. Rochester. Upon reaching Thornfield she finds it in ruins and goes in search of him in the village. If we accept that Jane is a realist and speculate that she has heard

\footnotetext{
18 The passage is often taken as proof of Charlotte Brontë's pro-feminism which runs as follows: "Women are supposed to be very calm generally: but women feel just as men feel; they need exercise for their faculties, and a field for their efforts as much as their brothers do; they suffer from too rigid a restraint, too absolute an stagnation, precisely as men would suffer; ...” (p. 96, Ch. XII).
} 
something of events at Thornfield, the burning of a great house would certainly be news, could it not be that her information is incomplete, and she sees a chance to regain her losses and hazards, an expedition to find the facts.

Certainly this takes Jane's return out of the realm of the supernatural and sets it firmly in the field of self-interest—and who can blame her if she does make a second attempt for Rochester's hand? Bertha's death would certainly be convenient, but is she sure? Examine her response "Dead?” Which response is she seeking? If Bertha has survived she has had a wasted journey, the situation remains the same and Mr. Rochester unobtainable. If the answer is in the affirmative then Jane may proceed with her plan. And what of Bertha's death? She was seen to "spring" in his presence before but always towards him, never away:

“Ah, sir, she sees you!" exclaimed Grace: You'd better not stay....

The lunatic sprang and grappled his throat viciously, and laid her teeth to his cheek. (p. 258)

Once again Bertha, as vampire, seeks blood, unafraid of Rochester, infuriated by the sight of him. Why, upon his approach on the roof does she flee, the extremity of flight, in fact, to her death below?

Why also would Rochester approach her as she teeters on the brink? He has made clear over and again that she has been the bane of his life, why would we assume his movement towards her to be benign? Bertha herself would not have so construed it, having suffered at his hand for years. If we were detectives investigating this case and having the facts before us, would we believe Bertha's death accidental or suicide? Hardly. Would we credit Jane's nocturnal summons with a psychic cause? Certainly not. These suggestions are not voiced to discredit Jane but to add to the points previously made in which her good sense, adaptability and, above all, awareness of her personal circumstances, are given as causes for her pragmatic decision-making. This may seem a brutal scheme of values but it is all she has to work with. Bertha dead is a problem solved, a barrier removed. If she has to tweak the narrative to allow for this then she will, the ex-servant's reiteration of Bertha's death is pregnant with self justification, not his but Jane's. Rather than searching for Brontë's true voice in the text and, thereby, attempting to graft onto it a proto-feminism of which the supporting evidence is scanty we should instead recognize Jane's true voice coming through that of the ex-servant. Far from being feminist, a thought Jane cannot indulge, she is the supreme realist, willing, in the final analysis to disregard even murder in the pursuit of her own safety and repose. Jane is an expression of Brontë in that both are women of dubious background, seeking success in a world so far out of their control that they must use any and all means either in their possession or available to them via an outside agency to get on.

One final note should be addressed to the book's dedication to Thackeray whom Brontë greatly admired and whose Vanity Fair was in serialization in 1847. By 1848 the book was completed. Becky Sharp, the consummate social climber, a woman acutely conscious of the pressing needs of her condition in society is, in the book's finale, revealed, far more explicitly to be quite more comfortable with murder and its concealment (burial at sea) should it prove expedient to herself. It would be interesting to know whether the finale of Jane Eyre provided any inspiration for Becky's actions and Joss's death. ${ }^{19}$

${ }^{19}$ For the twisted and provocative ending of Vanity Fair, see chapter 67 of the novel. 


\section{References}

Austen, J. (1998). Mansfield park (A Norton critical edition). C. L. Johnson, (Ed.). New York: Norton \& Company.

Briggs, A. (1983). A social history of England. London: Weidenfeld and Nicolson.

Brontë, C. (1971). Jane Eyre (A Norton critical edition). R. J. Dunn, (Ed.). New York: W. W. Norton.

Brontë, C. (2008). Villette (Oxford world's classics). M. Smith, (Ed.) with an introduction by T. Dolin. Oxford: Oxford UP.

Brontë, C. (1987). The professor (Oxford world's classics). M. Smith and H. Rosengarten (Eds.) with an introduction by M. Smith. Oxford: Oxford UP.

Brontë, E. (2003). Wuthering Heights (4th ed., a Norton critical edition). R. J. Dunn, (Ed.). New York: W. W. Norton.

Gaskell, E. (1996). The life of Charlotte Brontë (Oxford world's classics). A. Easson, (Ed., intro., and notes). Oxford: Oxford UP. Gérin, W. (1967). Charlotte Brontë: The evolution of genius. Oxford: Clarendon.

Gilbert, S. M., \& Gubar, S. (1979). The madwoman in the attic: The woman writer and the nineteenth-century literary imagination. New Haven: Yale UP.

Ingham, P. (2006). The Brontës. Oxford: Oxford UP.

Miller, L. (2002). The Brontë myth. New York: Vintage.

Oxford English Dictionary (2nd ed.). (1989). Oxford: Clarendon Press.

Poliakoff, S. (2003). The lost prince. A BBC drama, London.

Poovey, M. (1997). Making a social body: British cultural formation, 1830-1864. Chicago: Univ. of Chicago P.

Rattle, A., \& Vale, A. (2007). Amelia dyer: Angel maker: The woman who murdered babies for money. London: Andre Deutsch.

Rhys, J. (1999). Wide Sargasso Sea (a Norton critical edition). J. L. Raiskin, (Ed.). New York: W. W. Norton.

Said, E. W. (1993). Culture and imperialism. New York: Alfred A. Knopf.

Showalter, E. (1977). A literature of their own: British women novelists from Brontë to Lessing. New York: Princeton UP.

Thackeray, W. (2008). Vanity fair: A novel without a hero. J. Sutherland, (Ed.). Oxford: Oxford World's Classics.

Tillotson, K. (1956). Novels of the eighteen-forties. New York: Oxford UP.

Web, I. (1981). From custom to capital: The English novel and the industrial revolution. Ithaca: Cornell UP.

Williams, R. (1970). The English novel: From Dickens to Lawrence. New York: Oxford UP.

Wood, P. (1991). Poverty and the workhouse in Victorian Britain. Phoenix Mill: Sutton Pub. Ltd.

Woolf, V. (1932). The common reader (first series). New York: HBJ.

Woolf, V. (1992). A room of one's own and three guineas. Oxford: Oxford UP.

\section{Biography}

Dr. Chen is professor of literatureat the Department of Foreign Languages and Literature, and Dean of the International College as well as the College of Humanities and Social Sciences \& Dean of the International College, Asia University, Taichung, Taiwan. He was the former President of Taiwan ESP Association and served as TESOL ESP IS Chair from 2013 to 2015. Dr. Chen obtained his doctoral degree in English at University of Maryland, College Park, in 1991, with the support of a Fulbright scholarship and a grant from National Science Council (now Ministry of Science \& Technology), Taiwan, and has ever since taught at various universities, both national and private, in Taiwan, such as National Sun Yat-sen University, National Kaohsiung First University of Science and Technology, Fooyin University, and Asia University, to name just a few. Aside from his teaching and research, Dr. Chen has served as chair and dean at five universities. His strength in particular lies in his ability to organize and coordinate academic programs and administrative duties. Dr. Chen's research areas mainly lie in Victorian literature, Post-colonial literature, and English for Specific Purposes (ESP). Dr. Chen is also a material writer and has published The Joy of Literature (2012) and English for Hospitality and Tourism (2013), etc. He is now working on Victorian novelists, a critical re-reading of classic texts. 